Informatika i sistemy upravleniya. - 2018. - No. 2(56). - P. 35-49.

Kharitonov D.I. (demiurg@dvo.ru), Parkhin R.V., Tarasov G.V.

Institute of Automation and Control Processes

\title{
MODELING MPI COLLECTIVE OPERATIONS IN TERMS OF PETRI NETS
}

An approach to model MPI operations for communications of process groups in terms of Petri nets is proposed. Large-block compositional model of the MPI environment is introduced along with notation extension of compositional Petri nets to reduce a description of components in the model. The model of the MPI communicator is described and examples of MPI collective operation models are presented.

Keywords: system modeling, Petri nets, message passing interface, MPI.

DOI: $10.22250 /$ isu.2018.56.35-49

For citation:

Kharitonov D.I., Parkhin R.V., Tarasov G.V. MODELING MPI COLLECTIVE OPERATIONS IN TERMS OF PETRI NETS // Informatika i sistemy upravleniya. - 2018. - No. 2(56). - P. 35-49. 